\title{
Meningeal Sarcomatosis
}

National Cancer Institute

\section{Source}

National Cancer Institute. Meningeal Sarcomatosis. NCI Thesaurus. Code C4334.

A rare condition characterized by diffuse spread of sarcoma cells throug hout the meninges. The neoplastic cells are derived from mening eal connective tissue. Clinically, this disorder may present as a fulminant pachymening itis and/or encephalitis. 